\title{
EXAMINING THE PUNISHMENT IN EXCESS OF BLOOD MONEY WITH EMPHASIS ON THE CRIME OF BEATING AND WOUNDING IN IRANIAN LAW
}

\author{
EXAMINANDO A PUNIÇÃO EM EXCESSO DE DINHEIRO SUJO COM ÊNFASE NO \\ CRIME DE ESPANCAMENTO E FERIMENTO NA LEI IRANIANA
}

\author{
Mohammad Mafi ${ }^{1}$
}

\begin{abstract}
The present article examines the discretionary punishment in excess of blood money with emphasis on the crime of beating and wounding. So far, several investigations have been conducted in the field of discretionary punishment punishments but the issue of discretionary punishment in excess of blood money has been largely neglected. The fundamental question raised in this article is that what are the jurisprudential principles of discretionary punishment in excess of blood money? And what is the approach of criminal law to discretionary punishment in excess of blood money, especially regarding the crime of assault? The present article is a descriptive-analytical and examines the question using the library method. The results of the reseblood money not predetermined indicate that according to the rule آلَتَّزْيرُ لِكُلِّ عَمَلِ حَرَامُ discretionary punishment punishments for forbidden matters that in this process, the reform of the offender, the reformer of society and public order are the most important jurisprudential principles in this regard. In this regard, the legislature in some cases, including some medical crimes and beatings in addition to blood money, has determined a penalty of discretionary punishment. Accordingly, public interest and order are required. In some intentional and unintentional crimes that have a public aspect or are related to the public interest, in addition to blood money, the punishment of discretionary punishment such as imprisonment should be determined.
\end{abstract}

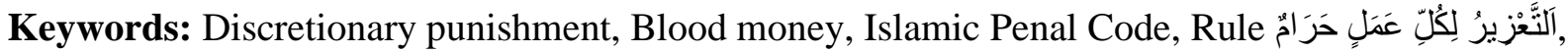
Public order

\section{RESUMO}

O presente artigo examina a punição discricionária em excesso de dinheiro sujo, com ênfase no crime de espancamento e ferimento. Até agora, várias investigações têm sido conduzidas no campo das punições discricionárias, mas a questão da punição discricionária em excesso de dinheiro sujo tem sido largamente negligenciada. A questão fundamental levantada neste artigo é investigar quais são os princípios jurisprudenciais da punição discricionária em excesso de dinheiro sujo? E qual é a abordagem do direito penal à punição discricionária em excesso de dinheiro sujo, especialmente no que diz respeito ao crime de agressão? O presente artigo adota uma abordagem descritivaanalítica e examina a questão usando o método bibliográfico. Os resultados do dinheiro sujo não

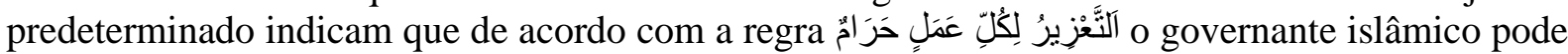
impor punições discricionárias em face de questões proibidas, sendo a reforma do infrator, do reformador da sociedade e da ordem pública são os princípios jurisprudenciais mais importantes a este respeito. A este respeito, o legislador em alguns casos, incluindo alguns crimes médicos e espancamentos, além de dinheiro sujo, determinou uma pena de punição discricionária. Assim, o interesse e a ordem pública são exigidos. Em alguns crimes intencionais e não intencionais que têm

\footnotetext{
${ }^{1}$ Master of Criminal Law and Criminology, Khorramabad Branch, Islamic Azad University, Khorramabad, Iran. ORCID: https://orcid.org/0000-0002-5959-6975. E-mail: Mohammad.mafi@gmail.com
} 
um aspecto público ou estão relacionados ao interesse público, além do dinheiro sujo, deve ser determinada a punição de punição discricionária, tal como prisão.

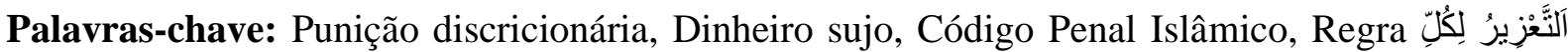
عَمَلٍ حَرَامُّ, Ordem pública

\section{INTRODUCTION}

Basically, in Iranian jurisprudence and law, punishments include retribution, prescribed punishment, discretionary punishment, and blood money. In some cases, in addition to the blood money, the discretionary punishment is also determined. This article examines this issue. In intentional crimes, if the victim or his guardians make peace in exchange for financial compensation instead of retribution, the amount of compensation is often determined in Islamic law but injured party or his guardians can make peace in terms of the amount of Bajani (Georgian, 1993: 286) Blood money is a punishment for preventing people from committing murder and for a person to be careful in his behavior so that he does not commit such a gross mistake; And this blood money is financial compensation. Because the loss of the victim causes an economic vacuum for his family and blood money fills this vacuum (Makar Shirazi, 2002: 148) Discretionary punishment is also a punishment that is not subject to the title of prescribed punishment, punishment or blood money and is determined and applied in accordance with the law in cases of committing sharia prohibitions or violating government regulations, type, amount, quality of execution and regulations related to reduction, suspension, fall and other sentences of discretionary punishment are determined by law. (Legal Vice President, 2013: 18) The Islamic Penal Code adopted in 2013, being bound by the principle of legality of punishments, has established a system of codified and definite punishments and it obliges the judge to comply with it and identifies the areas of authority of the judge, including mitigation, conversion, suspension, parole and aggravation or addition of punishments. (Encyclopedia, General Punishment, 2013: 253) In some cases, in addition to the blood money, the punishment of discretionary punishment has been determined. According to Article 614 of the Punishment Law of 1996: "Anyone who intentionally inflicts an injury or a blow to another that causes the loss, fracture or disability of a limb or leads to permanent illness or the loss or defect of one of the senses or interests or dementia of the insane, in cases where retaliation is not possible, if his action disrupts the order and protection of the society or the perpetrator or others, he will be sentenced to two to five years in prison, and at the request of the perpetrator, the perpetrator will also be sentenced to pay a blood money." Also according to Article 616 of the said law in case of unintentional murder due to carelessness or negligence or committing an act in which the perpetrator was not skilled or due to non-compliance with the system, the perpetrator will be 
sentenced to one to three years in prison and to pay a blood money if requested by the parents unless it is a pure error. The fact of the matter is that governments need to set rules to maintain public order and social peace to regulate citizen relations in such a way that everyone can enjoy their privileges without threatening the privileges of others. No rule of law should be "without a guarantee of performance" and punishment must be the inevitable consequence of violating it. Based on what has been said, the main question that is raised and examined in this regard is that what are the jurisprudential principles of discretionary punishment in excess of blood money and what is discretionary punishment in excess of blood money for assault in Iranian criminal law? In order to study the mentioned question, first the jurisprudential principles of discretionary punishment in excess of blood money are examined and then the discretionary punishment in excess of blood money is examined with emphasis on the crime of beating and wounding.

\section{JURISPRUDENTIAL PRINCIPLES OF DISCRETIONARY PUNISHMENT IN EXCESS OF BLOOD MONEY}

As mentioned, in some crimes in Iranian criminal law, in addition to the blood money, discretionary punishment is also considered. For example, according to Article 624 of the 1996 Penal Code: "If a doctor or midwife or pharmacist and persons acting as a doctor or midwife or surgery or pharmacist, conditions of abortion Provide and or direct an abortion, they will be sentenced to two to five years in prison and will be sentenced to pay a blood money in accordance with the relevant regulations. Also in accordance with Article 714 of the said law, whenever carelessness or non-compliance with government regulations or incompetence of the driver (whether land, water or air vehicles) or the owner of a motor vehicle leading to unintentional homicide, the perpetrator is sentenced to six months to three years in prison and to pay a blood money if requested by the parents. But what is the basis of discretionary punishment in excess of blood money in such cases from a jurisprudential point of view? In the present article, this issue is examined.

As a rule الَنَّزِْيرُ لِكُلِّ عَمَلِ حَرَامُ The Islamic ruler can determine the punishment for the cases that he deems to be forbiden. Phrases such as "This is in the possession of the Imam" (Nouri, 1988, J 18: 195) "To the extent that the ruler deems fit" (Amili, Bita, 2006: 584) "The Imam will punish him" (Nouri, the former, vol. 18, p. 156) "It is on the Imam" (Nouri, the former, vol. 18, p. 138) "As much as the ruler deems fit" (Mofid, 1990: 795) "To the extent that the ruler of Islam deems it appropriate". (Sheikh Mofid, the former, p. 795) "So much so that the ruler sees fit". (Ibn Zohra, Bita: 624) "It is entrusted to the Imam" (Tusi, 1972, J 8: 69) "He is with the Imam" (Tusi, 1996, J 2: 493) "As much as Imam knows." (Hali, 1985: 568) "His discretionary punishment is in disposal 
of the Imam." (Najafi, 2019, J 41: 69) And other expressions with the same theme that can be seen in the jurisprudential literature, all indicate the delegation of authority to the ruler. This can also be seen in the statements of the jurists that the execution of discretionary punishment is at the disposal of the ruler. For example, Sheikh Mofid (RA) says, "Anyone should give Muslims the impermissibility of ugly acts except adultery and sodomy ... in this case, there is no limit to adultery and sodomy." But it causes discretionary punishment and discipline, according to the ruling of the ruler "(Sheikh Mofid, the former, p. 795) or Ibn Zohra (RA) considers discretionary punishment to be valid according to what the guardian of the matter or the first of the affairs deems appropriate. (Ibn Zohra, the former, p. 624) Sheikh Tusi (RA) comments on Discretionary punishment with the phrase "Discretionary punishment is subject to the Imam" (Tusi, 1972, J 8: 69) and writes in another place: "Discretionary punishment is for the Imam and there is no difference in this matter" (Tusi, 1996, J 2: 493) Abu al-Salah Halabi (RA) considers the execution of discretionary punishment as the duty of the ruler of Sharia (Halabi, 1980: 417) and Ibn Idris (RA) considered this as one of the duties of his ruler or deputy. (Ibn Idris, 1991, vol. 3: 535) The same opinion is expressed by Mohaghegh Hali (RA) (Najafi, 2019, J 41: 69) Yahya bin Saeed Hali (H) (Hali, 1985: 568) Sahib Jawahir (RA) (Najafi, 2009 , J 41: 69) Allama Hali (RA) (Hali, 1992, vol. 3: 761-770) Sheikh Hur Ameli (RA), Ameli, the former, vol. 18, p. 383) and other jurists have expressed that the discretionary punishment is entrusted to the Imam and not the judge. Which is omitted from mentioning them and it is emphasized that this argument is not opposed and all jurists agree in delegating the matter to the ruler (Amid Zanjani, 2007: 155) and if anyone has interpreted the judge, it is because he considered judging to be a matter of government.

\section{2-1- CORRECTION OF THE OFFENDER AND THE INTEREST OF THE SOCIETY}

One of the reasons for the punishment of discretionary punishment is the correction and improvement of the offender. Correction and training of the offender, which is known as one of the goals of modern criminal law and has been theorized around it, in the Islamic penal system, one of the most important goals is considered to be that if these goals are achieved without the implementation of punishments, the punishment will be abolished. Acceptance of amnesty and repentance as two complementary institutions alongside the institution of punishment reflects this fact. In addition, perhaps the most important basis and foundation that can be introduced for the system of punishments is this concept of expediency. However, in books and articles that have been prepared and compiled after the Islamic Revolution of Iran and in the light of the concept of "government decree", the concept of expediency has been considered more from the point of view 
of its relationship with the government decree (Hosseini, 2009: 1). However, its effect and nature in the field of religious punishments cannot be ignored.

Expediency has a long history in Islamic jurisprudence. This history can be seen even among Islamic theologians and rationalists. According to the sect of schismatics, good and bad deeds are inherent and irreversible, so that even God does not transgress them. (Al-Fakhouri, p. 135) But in the field of Shiite jurisprudence, expediency as an independent chapter has not received much attention and has been used only transiently alongside other arguments and as a reinforcer of other arguments. In the books and words of classical Shiite jurisprudence, our jurists, following the use of this word in the narrations, have deduced this word in books such as the book of Al-Kharaj, the book of Al-Waqf, the book of Al-Bayy, the book of Al-Jihad, etc. But they have passed without explanation (which may not have needed to be explained in the circumstances of that time) (Sarami, 2001: 71). Sunni jurists consider the basis of expediency to be the interests of the messenger, but Shiite jurists refer to expediency or to the Sunnah, by considering expediency as recognizing the instances of general Shari'a rulings, as the Shari'ah has said, the preservation of the soul or religion is obligatory, but it has not specified its instances in all cases, but has left the discernment to the qualified world; Or they return the expediency because of the intellect in such a way that whenever the intellect is cut off from the existence of an expediency that was not contrary to any of the Shari'ah arguments and it was appropriate to forge a ruling, undoubtedly, he can make a verdict based on it. Therefore, expediency based on the interests of the messenger is considered a valid religious reason according to Sunni jurisprudence and from the Shiite point of view, it is not considered an independent reason, and if it refers to tradition and reason, it is valid (Qadir, 2011: $35)$.

\section{2-2- PUBLIC ORDER}

Governments, in order to maintain public order and social order, have to establish rules so that citizens' relations can be regulated in such a way that everyone can enjoy their privileges without threatening the privileges of others. However, the explanation that the main purpose of law is to maintain security. It becomes clear why no rule of law should be "without a guarantee of enforcement" and punishment should be the inevitable consequence of its violation. No legal school or system can be independent of security and without disciplinary policies; otherwise, the relation to the cause and philosophy of its existence is disregarded and cannot be sustained. Islam, as a legal system of society that meets the individual, individual and social needs of human beings at all times and places, is no exception to this rule. A brief look at the sources of Islamic law shows that, from an internal religious perspective, all "security" is the first condition for a healthy society. It was to 
create security that Dhu al-Qarnayn undertook the most arduous work and prevented it from becoming a proverb in history and a symbol of strength, permanence and survival. (Makarem Shirazi; Others, 1995, J 12: 539) Prophet Ibrahim (AS), while building the Kaaba, paid attention to this natural need and asked God to make the land a blessing of "security" (Abraham / 35) and God made it as a safe house for the people (Baqara / 125) This attribute is so important that it makes God bless man and makes him worthy of thanksgiving. (Quraysh / 3-4) God swore by this safe land to express the quality of human creation. (Teen / 3-4) Creating order and peace in society is the goal that it has been followed in all jurisprudential rulings, even in worships and transactions, to the extent that the precedence of "people's rights" over "divine rights" is accepted and practiced as an indisputable rule of jurisprudence. The verdict of the most severe treatment of the usurpers of the rights of the people is a sign of the holy shari'ah's concern for the protection of the rights of the citizens, even in the financial dimension. The rulings of jurisprudence in various chapters such as enjoining the good and forbidding the evil, judgment, usurpation, lactation, limits, retribution and blood money can all be analyzed in this regard. And basically, the philosophy of jurisprudence, from the beginning to the end, is for him to regulate human relations and provide inner and social peace, in order to achieve the goal of his creation in the shadow of it.

\section{3- PUNISHMENT OF DISCRETIONARY PUNISHMENT IN EXCESS OF BLOOD MONEY IN BEATINGS AND INJURIES}

"Beat" refers to injuries that occur to the body without fracture or bleeding and cause effects such as bruising, redness, bruising, blackening and twisting. "Injury" also refers to injuries that lead to the rupture of body tissues. Injury is often accompanied by bleeding, such as scratching or tearing of the skin or breaking a bone, and amputation or amputation. According to the Shari'a and the law, it guarantees the importer of the beating or the cause of the injury, and according to the law, this damage must be compensated as a human right by performing punishment or paying blood money.

\section{3-1- IN INTENTIONAL CRIMES}

In premeditated crimes such as premeditated murder, the main and primary punishment for assault is retribution. That is, just as the relatives of the victim (first-degree relatives of the victim who own his blood) can request that the killer be killed. According to Article 386, punishment of intentional crime against a member at the request of the defendant or his guardian, Existence of other conditions stipulated in the law, retribution and otherwise according to other articles of this law in terms of blood money and discretionary punishment. Anyone intentionally injuring or 
injuring another who causes the mutilation or breakage or disability of a limb or leads to permanent illness or the loss or mutilation of one of the senses or interests or dementia of the insane; In cases where retribution is not possible, if his action disturbs the order, protection and security of the society or the perpetrator's fear or the others, he will be sentenced to 2 to 5 years in prison, and at the request of the victim, the perpetrator will also be sentenced to pay blood money. Therefore, one of the hypotheses that the perpetrator of beating and wounding is sentenced to discretionary punishment in addition to blood money, is when, at the discretion of the judge, his action has disturbed the order and security of society. In other cases, in addition to the blood money, the perpetrator may also be sentenced to discretionary punishment. One of these cases is when the injury does not lead to the above injuries, but the tool of the wound is a gun or a knife and the like. In this case, the perpetrator will be sentenced to 3 months to one year in prison. In addition, if some people quarrel with each other, if this collective conflict leads to beatings and injuries, each party to the conflict is sentenced to between three months and one year in prison, as the case may be. The assailant may like the act of beating by his members like hands and feet and teeth or use other tools such as stones, sticks, knives, weapons and...If the injury does not lead to the above-mentioned severe injuries, but the assailant (importer of the blow) has used a weapon or a knife and the like, according to the note of Article 614 of the Penal Code of the Islamic Penal Code approved in 1996, he will be sentenced to three months to one year in prison. Thus it is observed that in Article 614 the results obtained from the crime are taken into account, and the note considers the "means" of committing the crime. Sometimes it is possible for someone to inflict a blow on another without the use of a cold or hot weapon, which leaves no visible traces, even to the extent of redness and bruising on the victim's body. In this case, the payment of blood money is canceled but, according to Article 567 of the Islamic Penal Code adopted in 2013, the perpetrator can be sentenced to 91 days to 6 months in prison or 11 to 30 lashes.

The punishment for the assailant to pay the blood money depends on the fact that the injured person must have complained and demanded the blood money of the injuries inflicted on him. However, if one of the two presumptions made in Article 614 or its note, namely beating, has led to one of the serious injuries contained in that article, or if a weapon and a knife were used, there is no need to sue the private plaintiff to prosecute the accused, and even without the injured person complaining, the judiciary prosecutes and punishes the accused. Because in this case, the crime of intentional assault is an unforgivable crime and there is no need for the plaintiff to file a complaint to prosecute the accused because by committing it, the society is harmed and for this reason, the crime has a public aspect. It should be noted that if the beating did not lead to severe consequences in Article 614 and no weapons or knives were used, the prosecution of the accused is subject to the complaint of the private plaintiff, and in this case, the injured person can only claim blood money. 
In the note of Article $614(\mathrm{BC})$ it is stated that if the injury does not lead to the losses mentioned in the article but the weapon is a knife and the like, he will be imprisoned from 3 months to 1 year which on 13/12/2017, a note was added to Article 617 of the 1996 Islamic Penal Code, according to which carrying a sword, a machete, a boxing claw if it was for the purpose of fighting and beating or supply and production to enter, is prohibited and criminalized, if the private plaintiff has also withdrawn his complaint, the prosecutor's office and the court will consider the general aspect mentioned in the note of Article 614 and the court will issue a legal ruling.

If the infliction of bodily harm meets the eight conditions set forth in Article 393 of the Islamic Penal Code of 1992, a person will be sentenced to retribution. In Iranian jurisprudence, due to the rule of precaution in the case of members and the impossibility of fulfilling the conditions set forth in Articles 393 to 416, retribution is rarely applied in the case of bodily harm which in terms of the jurisdiction of the courts, the crime punishable by amputation is also tried in a criminal court under Article 302 of the Code of Criminal Procedure.

Article 567 of the Islamic Penal Code adopted in 2013, which states: "In cases where the perpetrator's behavior does not cause harm or defect in the body or leaves a mark on the body, the guarantee is revoked, but in intentional cases, if not reconciled, the perpetrator will be sentenced to seventh degree imprisonment or flogging." It is a founding thing in the Iranian criminal law that causing damage did not result in any effect and did not cause injury or breakage and only damage has been done which has caused the discretionary punishment to which the legislator has responded in the form of 7th degree imprisonment or flogging, although the criminal legislature cannot propose and must act in the form of punishment or deterrent behavior, in this article, he has postponed the application of his punishment to the second degree, after not compromising, that it was better to deal decisively, while in forgivable crimes, reconciliation and pardon suspend the punishment that the mentioned article is among the forgivable crimes and there was no need to postpone the punishment in this article after peace or non-reconciliation and in terms of writing, it deserves to be a comprehensive and expressive law. Whenever because the intentional behavior of the perpetrator did not cause harm or defect in the body nor left a trace of himself in the body, even if the blood money cannot be demanded, the perpetrator can be sentenced to 7th degree imprisonment or flogging, which according to Article 19 of the Islamic Penal Code of 2013 to 91 days to 6 months imprisonment or 11 to 30 lashes that according to Article 66, the conversion of imprisonment into alternative punishments to imprisonment is mandatory.

Article 393- In retaliation of a member, in addition to the general conditions of retaliation, the following conditions shall be observed in detail in this law:

A- The location of the member to be retaliated against is the same as the crime.

B- Retribution should be equal to the amount of the crime. 
$\mathrm{C}$ - There is no fear of losing the perpetrator or harming another member.

D- Retribution of a healthy limb is not against an unhealthy limb.

E- The retribution of the main member is not against the non-original member.

C- The retribution of a full member against an incomplete member is not.

Note: If the offender does not have a right hand, his left hand and if he does not have a left hand, his foot will be retaliated against.

The Legal Department of the Judiciary stated in Advisory Opinion No. 7288/7 dated $12 / 11 / 2001$ during the rule of the former Islamic Penal Code, "obeying a simple beating that leaves no trace in the beating is a crime and the perpetrator will be sentenced to pay according to Article 367 of the Islamic Penal Code approved in 1991 and 559." The same office stipulates in advisory theory No. 716916 dated 27/12/1988, which we also mentioned in the first chapter, "intentional beating, if it does not cause discoloration or swelling of the position, in terms of lack of proof of retribution or lack of forgiveness of the private plaintiff requires the determination of the throne according to Article 210 of the former law and 449 of the Islamic Penal Code, approved by the ruler in 2013." These two views are incorrect, because when no trace is left on the battered body, there is no basis for determining the throne referred to in the previous Article 367. At the same time, the article referred to "crime against an organ", and it is unlikely that a simple multiplication without the slightest effect could be described under such a heading.

Of course, in some other consultative theories, the mentioned office has considered beating in some cases as a crime of insult. At present, in such a case, the provisions of Article 567 of the Islamic Penal Code approved in 2013 should be considered.

With these descriptions, it seems that Article 567 is the only debatable example of that noninjury multiplication, because the inquiry law provides for insults and behavioral insults, which is subject to the crime of insulting the subject of Articles 608 and 609 of the Penal Code of 1996 that "words that are explicit or apparent, or committing acts and actions that, according to the customs of society and taking into account the temporal and spatial conditions and descriptions of people, cause their reduction and humiliation and with the non-appearance of words is not considered an insult 30/12/2000 and advisory theory No. 7300/7 dated 4/1/1999 stipulates, the objection of beating without a mark cannot be equated with insult unless the mystics consider it an insult."

\section{3-2- IN INTENTIONAL CRIMES}

If there are no general and specific conditions of retribution, the perpetrator will be sentenced to pay blood money. Therefore, in the case of unintentional crime against the members and intentional crime in which there is no retribution or retribution is not possible or the 
compromised blood money has been paid, the blood money is paid. Articles 558 et seq. Of the Islamic Penal Code state the general rules of blood money for members.

A "bruise" is damage to the limbs without fracture or bleeding that causes bruising, redness, bruising, blackening, and twisting. The law stipulates a blood money for each of these cases, which the assailant must pay to the victim. The penalty for injuries that cause skin discoloration is as follows in the Islamic Penal Code:

Blackening of the skin of the face, six thousand;

Its bruising, three thousand;

And frying it, one and a half thousandths of a full blood money

Discoloration of the skin of other organs, as the case may be, half of the above values.

In this ruling, there is no difference between whether the member has a specified blood money or not. Also, there is no difference between discoloration of all or part of the limb and survival or deterioration of its effect. Injury that causes swelling of the body, head or face has an "blood money not predetermined" and if, in addition to swelling, it also changes the color of the skin, depending on the case, the blood money and the amount of color change will be added to it. Blood money not predetermined refers to the amount of money that is paid as compensation for financial or physical damage and for which no amount is specified in the law.

Loss of members or loss of benefits in many cases of Iranian criminal law carries a penalty of only blood money. Those are the organs that appear, such as hands, feet, eyes, ears, lips, nose, and tongue. The general rule is that a person's organs (such as tongue, nose, neck, spine, spinal cord, eyelids, and genitals) have full blood money. (Article 563 of the "Islamic Penal Code", approved in 2013). The blood money mentioned in Article 592 (nose) 611 (tongue) 626 (neck) 647 (spine) 648 (spinal cord) 662 (penis) 664 (female genitals) is determined as the amount of full blood money. The blood money of each member of the couple (such as eyes, ears, lips, jaws, hands, feet, breasts, both sides of the female genitals and testicles) is equal to half of the full blood money and the destruction of both of them is equivalent to full blood money (Article 563 of the "Islamic Penal Code") Because according to the narration, ما كان في الجسد منه اثنان فقيه نصف الديه" blood money of the members of the couple mentioned in order in the materials, 587 (eyes) 600 (earlobes) 607 (lips) 629 (jaws) 635 (hands) 646 (feet) 669 (breasts) 664 (each on both sides of the female genitals) and 665 (testicles) are mentioned. It should be noted that some members of the couple have more blood money than other members, for example, according to Article 665, the left testicle's blood money is two-thirds of the full blood money and the right testicle's blood money is one third of the full blood money. Likewise, although the blood money for a total of four eyelids is equivalent to the full blood money, however, according to Article 590, the blood money for each upper eyelid is onesixth and the blood money for each lower eyelid is one-fourth of the full blood money. The 
elimination of benefits, which means the benefit, is the use that expects from each organ and system of the body, including the best of the five human senses.

Losing one's intellect or destroying an important benefit or sense completely, will result in full blood money but if the importance of that feeling or benefit is not so great, it will be given less blood money or more, therefore, the blood money for destroying the sense of touch and the sense of taste only causes Blood money not predetermined and not the full blood money.

A noteworthy point regarding Article 401 of the Penal Code of 2013is that it has a general aspect for injuries such as discoloration and swelling, which is not without its problems, this is not the case for minor head fractures and head fractures that bleed, however, in an injury that reaches the brain, a fracture in the bone and an injury that protrudes the bone, and in addition to the blood money, a person with a broken bone will be sentenced to discretionary punishment in Article 614, according to a law professor.

"In the Islamic Penal Code adopted in 2013, only the punishment provided in the last article has been referred to. Therefore, these cases do not create an obligation for this law. However, despite the explicitness of Article 401 Islamic Civil Code With the inclusion of the punishment provided for in Article 614 (Book V) in all the instances contained therein, the question remains that is it possible to refer to the rationale of Article 401 Islamic Civil Code injuries that only cause discoloration of the skin or inflammation of the body are listed as other injuries to the substance, such as bruises or fractures and sentenced the perpetrator to two to five years in prison? Is this part of Article 401: "... injuries that cause discoloration or swelling of the body ..." also subject to the discretionary punishment prescribed in Article 614? This ambiguity according to the ruling of Article 567 Islamic Civil Code, this is especially true for cases where there is only one degree of slight skin discoloration. According to the beginning and below of Article 401 of the Islamic Civil Code, it seems that the focus of the legislator in this article is the expulsion of instances of intentional crime against a member, including retribution, and not focusing on discretionary punishment all of them according to Article 614 (Book 5). Therefore, in interpreting this article, one should think of measures and not just consider changing the color to be subject to retribution, rather, it excluded severe and disproportionate punishment from Article 614 of Book V; In particular, in the Islamic Penal Code adopted in 1991, which is now obsolete, the perpetrator of such injuries is also excluded from the scope of Article 614 of the fifth book, and considering the criminal policy of the Islamic Penal Code of 2013, which tends more towards impunity and impunity, with the slogan of loyalty to the principle of legality of punishments, criminal justice cannot be slaughtered at once. Moreover, in any case where we encounter an explicit text that is not in line with the principles and rules of criminal law, the opinion of the legislator must be obtained, as the case may be and based on the conditions governing it, in such a way that we are not accused 
of inferring against clear words by rationalists, you know that the field is Simorgh and while having courage, it must be done with all the principles and conditions. We must always keep in mind that the necessary premise of legal excellence is awareness along with courage. With a brief look at the amount of blood money for injuries that cause skin discoloration (Article 714 of the Civil Code) In comparison with the blood money of the other crimes mentioned in Article 401 of this law and the care in taking out the harassment (Article 709 - paragraph A - harassment - scratching the skin without bleeding, one hundredth of the full blood money) From the examples mentioned in Article 401, it should be concluded that the punishment for an injury that reaches the brain sac, an injury that tears the membrane of the brain and reaches the brain, cannot be punished and .... equated with injuries that only cause discoloration of the skin or swelling of the body.

According to Article 714: "The compensation for injuries that cause skin discoloration is as follows:

A: Blackening of the skin of the face, six thousandths, bruising, three thousandths and redness, one and a half thousandths of full blood

B: change of skin color of other organs, as the case may be, half of the values mentioned in paragraph (a)»

Also, refrain from referring to head injuries that break the skin, fractures of the head that bleed, head fractures that reach the flesh, injuries that cause piercing, skin that is between the flesh and bone, and head fractures that reach the bone, (Articles 709 and 713) In Article 401 of the Islamic Civil Code, only because of the possibility of retribution, there is another analogy that in this article, the legislator has emphasized the abolition of punishment and not necessarily the same discretionary punishment for all authorized titles. The Judiciary Law Office believes in the inclusion of Article 614 of the Civil Code of the Islamic Republic (Book V) in the theory of 1051/7/7 - 6/4/1392 regarding skin discoloration and inflation: The Judiciary Law Office believes in the inclusion of Article 614 of the Civil Code of the Islamic Republic (Book V) in the theory of 1051/7/7 - 27/6/2013 regarding skin discoloration and inflation: "The discretionary punishment prescribed in Article 401 of the Civil Code of 2013 and its reference according to Article 447 of the same law to Article 614 of the fifth book of the Islamic Civil Code of 1996, only includes the cases that intentional beatings and injuries result in the effects set forth in this article, which include "the loss or fracture or disability of a limb or permanent illness or loss of one of the senses or interests or dementia of the savior against" or subject to its comment, therefore, an injury that merely causes skin discoloration and swelling without having the above effects, It is not subject to the discretionary punishment mentioned in Article 614 of the Islamic Civil Code of 1996 and in general, with the enactment of the Islamic Civil Law of 2013, intentional crimes that cannot be retaliated against are subject to 
interpretation if it is one of the examples of Article 614 of the Islamic Civil Code and its commentary. (Aghaei Nia, 2016: 318)

And another professor believes that the discretionary punishment prescribed in Article 401 of the Islamic Penal Code of 2013 and its reference according to Article 447 of the same law to Article 614 of the Islamic Penal Code of 1996 only includes cases that intentional beating resulting from the effects set forth in this article means "loss or fracture or disability of a limb or permanent disease or loss or defect of one of the senses or benefits or dementia" or is subject to its comment. Therefore, an injury that merely causes discoloration of the skin and swelling of the body, without having the above effects, it is not subject to discretionary punishment mentioned in Article 614 of the Islamic Penal Code of 1996, and in general, with the approval of the Islamic Penal Code of 2013, intentional crimes that cannot be retaliated against can be discretionary punishment if, which is one of the examples of Article 614 of the Islamic Penal Code of 2013or its commentary, the principle of legality of crime and punishment and narrow interpretation of criminal law also confirms this theory. Of course, in this case, the provisions of Article 401 of the "Islamic Penal Code" should also be considered that in crime, an injury that reaches the bladder, an injury that reaches the brain, an injury caused by the penetration of an injury weapon into the body, a fracture in a bone without detachment, an injury that protrudes a bone, a bone fracture, and injuries that cause discoloration of the skin or swelling of the body cancel the punishment and the perpetrator, in addition to paying blood money, is subject to the discretionary punishment prescribed in the "Law of Discretionary punishment". According to the mentioned article, the same ruling is valid in any other case where there is a risk of rape in retaliation of members or interests. (Mir Mohammad Sadeghi, 2015: 285) In any case, the redness of the skin, which is accompanied by a thousandth and a change in the color of the wax, is a full blood money, and has been punished with a general aspect. Article 567 of the Islamic Penal Code adopted in 2013, which is considered as a founding matter in the Iranian Penal Code, which the injury did not lead to any effect and did not cause any injury or fracture, and only the injury that caused the discretionary punishment was done that the legislature has responded in the form of 7 th degree imprisonment or flogging, although the criminal legislature cannot propose and must act in the form of punishment or deterrent behavior, in this article, he has postponed the application of his punishment to the second degree, after not compromising, it was better for him to be decisive, while in forgivable crimes, he stopped compromising and forgiving the punishment, which this article is one of the forgivable crimes and there was no need to postpone the punishment in this article after peace or non-reconciliation and from the point of view of writing, it is appropriate that the law be comprehensive and expressive.

Whenever because the intentional behavior of the perpetrator did not cause harm or defect in the body nor left a trace of himself in the body, even if the blood money is not demanded, the 
perpetrator can be sentenced to 7th degree imprisonment or flogging according to this article, which according to Article 19 of the Islamic Penal Code of 2013 to 91 days to 6 months imprisonment or 11 to 30 lashes that according to Article 66, the conversion of imprisonment into alternative punishments to imprisonment is mandatory. The Legal Department of the Judiciary stated in Advisory Opinion No. 7288/7 dated 11/12/2001 during the rule of the former Islamic Penal Code, "simple beating that leaves no trace in the beating is a crime and the perpetrator is sentenced to pay Arash according to Article 367 of the Islamic Penal Code adopted in 1991, the current Article 559." The same office stipulates in the advisory theory No. 716916 dated 27/12/1988, which we also mentioned in the first chapter, "intentional beating, if it does not cause discoloration or swelling of the position, in terms of lack of proof of retribution or lack of forgiveness of the private plaintiff requires the determination of the throne according to Article 210 of the former law (449 Islamic Penal Code, approved in 2013) by the ruler", these two views are not correct, because when no trace is left on the beaten body, there is no basis for determining Arash, which was mentioned in the previous Article 367. At the same time, the article referred to "crime against an organ", and it is unlikely that a simple multiplication without the slightest effect could be described under such a heading.

Of course, in some other consultative theories, the mentioned office has considered beating in some cases as a crime of insult. At present, in such a case, the provisions of Article 567 of the Islamic Penal Code approved in 2013 should be considered.

With these descriptions, it seems that Article 567 is the only debatable example of that noninjury multiplication, because the law provides for the removal of ambiguity related to insult and behavioral insult, which is subject to the crime of insult, the subject of Articles 608 and 609 of the Punishment Law of 1996, which "Words that are explicit or explicit and or committing acts and movements that, according to the customs of the society and taking into account the temporal and spatial conditions and descriptions of persons, cause their reduction and humiliation and are not considered insults by the absence of the words 30/12/2000 and advisory Opinion No. 7300/7 dated 4/1/1999 stipulates that the objection of multiplication without a mark cannot be equated with insult unless the mystics consider it an insult."

\section{CONCLUSION}

The results of the reseblood money not predetermined showed that the punishment of discretionary punishment is in excess of blood money in laws that mainly have the aspect of maintaining public order and interests. In fact, the public interest and public order of the society is the most important basis for imposing discretionary punishment in excess of the blood money, 
which is imposed according to the rule of al-discretionary punishment for all the acts of forbiden. The results of the reseblood money not predetermined also showed the crime of assault, the legislature has responded to five types of infliction of bodily harm that principle of proportionality of crime and punishment has not been observed, and especially in Article 401 of the Penal Code of 2013 for skin discoloration or swelling of the body, the punishment for the crime is the subject of Article 614 of the Penal Code of 1996. This type of injury is not comparable to the crimes of injuries that reach the brain sac and injuries that reach the brain and on the other hand, there is no discretionary punishment reaction for cases such as the head that splits the skin and the skin that has more blood money than skin discoloration or swelling and in the case of ineffective assault, which is the lowest of the intentional crimes against the soul ,the imposition of a 7 th degree punishment is very unfair, because in some cases only the blood money is determined, and a sentence of one hundred thousand tomans will be much more favorable, even if it has effects, so that the case of beating has left no effect and will result in imprisonment of up to 6 months or flogging of up to 30 blows and there is no correlation between these cases that this article is not compatible with the basic principles of criminal law and a clear example is the "fatwa of criminal legislation" and from a "case in jurisprudential event" has entered the Assembly of Criminal Law and perhaps those who have committed this incorrect act who have provided incomplete and incorrect translations of jurisprudential texts in the name of the Penal Code of 2013 that would have been better if the injury had been in the form of offensive behavior, consider it only a crime of insult, and it is suggested that numerous and sometimes disproportionate reactions be regulated in the Islamic Penal Code, and especially in the organization of the punishment section.

\section{REFERENCES}

Al-Makarim Al-Shirazi, Nasser. (2002). Important Jurisprudential Reseblood money not predetermined, School of Imam Ali bin Abi Talib (peace be upon him), Qom, first edition.

Amid Zanjani, Abbas Ali. (2007). Rules of Jurisprudence of Criminal Law, Volume 2, First Edition, Samat Publications and Institute of Islamic Studies and Reseblood money not predetermined.

Amili, Muhammad bin Al-Hassan bin Ali Al-Hurr. (2006). The Shiites' means to collect the Sharia, by Al-Rabbani Al-Shirazi, Abd Al-Rahim, Volume 18, Beirut, House of Revival of Arab Heritage, BTA.

Elahi Manesh, Mohammad Reza. (2014). Criminal Law and Medical Violations, Tehran, Majd Publishing.

Encyclopedia, General Penalty. (2005). Department of Law and Political Science, Tehran, 2013.

Georgian, Abu al-Qasim. (1993). Legal Articles, Vol. 1, Tehran, University of Tehran. 
Halaby, Taqi al-Din bin Najm al-Din (Abu Salah). (1980). al-Kafi fi fiqh, his library, Imam Amir al-Mu'minin (peace be upon him), Isfahan.

Helli, Abu Mansur Hassan bin Yusuf bin Ali bin Al-Mutahhar. (1992). (a scholar) of the various Shiites, Volume 3, Qom, Center for Reseblood money not predetermined and Islamic Studies.

Helli, Yahya bin Saeed. (1985). Al-Sharia Mosque, Qom, Sayyid Al-Shuhada Scientific Institution.

Hosseini, Seyyed Ali. (2010). A Look at the Evolution of Expediency in Shiite Jurisprudence, Tolo, No. 1.

Ibn Idris Helli, Muhammad Ibn Idris. (1991). Sarir Al-Hawi, Tahrir Al-Fatawa, Volume 3, Qom, Publications of the University of Teachers.

Ibn Zahra. (2007). Ghaniyat al-Nuzu' (The Fiqh Mosques) Qom, B. Ta.

Legal Vice President, Islamic Penal Code, December 2013.

Makarem Shirazi. (1995). Nasser and others, Tafsir Nomoneh, vol. 12, Tehran, Islamic Library.

Mir Mohammad Sadeghi, Hossein. (2006). "Comparative Study of Abstinence as a Material Element of Crimes Against Individuals", Journal of Legal Reseblood money not predetermined, No. 43.

Mir Mohammad Sadeghi, Hossein. (2015). Crimes against persons, Tehran, Mizan Publishing, 19th edition.

Mofeed, Muhammad bin Noman. (1990). (Sheikh), Al-Maqnah, Qom, Publications of the University of Teachers, p. 795.

Mr. Nia, Hossein. (2017). Crimes against Persons - Spiritual Personality, Tehran, Mizan Publishing.

Najafi Muhammad Hassan. (2009). Jawahar al-Kalam fi al-Sharh al-Shara'i al-Islam, Chap Shashem, Volume 41, Tehran, Islamic Library.

Najafi Muhammad Hassan. (2019). Jawahir al-Kalam fi al-Shara' al-Shari' al-Islam, Chap Shashem, Volume 41, Tehran, Islamic Library.

Nouri, Hussein. (1988). Mustadrak Al-Wasail, Volume 18, Beirut, Aal al-Bayt Institute for Heritage Revival.

Qadir, Mohsen; Sarikhani, Adel. (2011). Governmental Rulings and Expediency in Shiite Jurisprudence, Shiism, Vol. 35, Fall.

Sadeghi, Mohammad Hadi. (2005). Crimes against Persons, Tehran, 8th edition, Mizan Publishing.

Sarami, Saifullah. (2001). Government Decrees and Expediency, Strategic Reseblood money not predetermined Center of the Expediency Council of Tehran: Abir Publishing. 
Toosi, Abu Jaafar Muhammad bin Hassan. (1972). Al-Mabsout in the Imamiyyah Fiqh, Volume 8, Tehran, Al-Murtaza Library.

Tosi, Abu Ja`far Muhammad bin Hassan. (1996). Al-Khalif fi Al-Ahkam, Volume 2, an Islamic publication book, published by the University of Teachers, the Seminary of Qom.

Trabalho recebido em 21 de junho de 2021

Aceito em 31 de outubro de 2021 